\title{
Effect of different growing media on the rooting of pomegranate (Punica granatum L.) cv. 'Phule arakta' cuttings
}

\author{
Rajkumar $^{1 *}$, Jagan Singh Gora ${ }^{2}$, Ramesh Kumar ${ }^{2}$, Anshuman Singh ${ }^{1}$, Ashwani Kumar ${ }^{1}$ \\ and Gajender ${ }^{1}$ \\ ${ }^{1}$ ICAR- Central Soil Salinity Research Institute, Karnal-132001(Haryana), INDIA \\ ${ }^{2}$ ICAR- Central Institute for Arid Horticulture, Bikaner-334006 (Rajasthan), INDIA \\ *Corresponding author. E-mail: rajhorticulture@gmail.com \\ Received: June 4, 2016; Revised received: January 9, 2017; Accepted: April 11, 2017
}

\begin{abstract}
To identify the most efficient growing medium for root and shoot development in stem cuttings of pomegranate cv. 'Phule arakta' under arid conditions, a greenhouse experiment was conducted in randomized complete block design with three replications during 2014-15 at ICAR-CIAH, Bikaner. About 15-20 cm long hard wood cuttings, 0.5$1.0 \mathrm{~cm}$ diameter and having three to four buds were separated from the healthy trees and planted in mid-January. Detached cuttings were treated with 2500 ppm of IBA (3- Indole butyric acid) using quick dip technique (for 5 seconds) and planted in five rooting substrates i.e. sand, vermiculite, perlite, cocopeat and garden soil (control) alone and in combination at 1:1 (v/v). The response of perlite + vermiculite medium was best in terms of rooting (82.33 per cent), number of roots (32.67 per cutting), fresh and dry weight of roots $(0.61 \mathrm{mg}$ and $2.08 \mathrm{mg})$, shoots per cutting (80.33) and survival (76.0 per cent) than the other medium used. Vermiculite + Coco peat 1:1 (v/v) combination also resulted in rooting in more than 80 per cent of cuttings whereas cuttings raised in garden soil and sand showed very low rooting. Based on the findings, it appears that Perlite + vermiculite $1: 1(\mathrm{v} / \mathrm{v})$ and vermiculite + cocopeat may be appropriate alternatives to the conventially used substrate, i.e., garden soil for the better rooting and establishment of pomegranate cultivar 'Phule Arakta' cuttings.
\end{abstract}

Keywords: Cocopeat, Cuttings, Perlite, Punica granatum L., Sand, Vermiculite

\section{INTRODUCTION}

Pomegranate (Punica granatum L.) family Punicaceae is one of the preferred table fruits in tropical and sub-tropical regions of the world. The wide adaptability, hardy nature, low input needs, high yields, better keeping quality and therapeutic values of fruits establish its value as a remunerative fruit crop in India and elsewhere. India is one of the largest producers of pomegranate in the world. During 2013-14, pomegranate was cultivated over 1.31 lakh ha with an annual production of 13.46 lakh tonnes and productivity of 10.27 tonnes/ ha in India (Vision NRC Pomegrante 2015). According to Larson (1980) the best planting media must have a $\mathrm{pH}$ favorable to optimum nutrient availability and texture which permits unrestricted gaseous exchange and water movement for the proper root development. Different media, other than routinely used garden soils such as perlite, vermiculite and cocopeat considerably improves the rooting in cuttings. Perlite is recognized to have a unique capillary action which makes it a superior growing medium. It is very useful for increasing aeration and drainage within the container because of its uniformity and lightness (Paradiso and de Pascale, 2008; Rajkumar et al., 2016). Percentage rooting and the quality of the roots produced are directly influenced by the medium used (Ansari, 2013). Thus, right selection of right rooting media should be given emphasis to obtain the desired results. Unexpected poor growth of the pomegranate seedlings in field after planting was ascribed to poor root development because of use of soil-based media in nurseries of tropical and sub-tropical areas of Africa, Asia, and Latin America. Different organic and artificial growing media consisting of ingredients such as compost, peat, or coconut coir have been found suitable alternatives to soil-based media for raising the cuttings because soil medium may be linked to the rapid loss of water from this medium (Miller and Jones, 1995). If a rooting medium contains soil, it should contain 10 to 30 percent soil amended with organic ingredients to promote the aeration and water flux while extending the water retention for longer periods of time (Landis, 1995). According to Walston (1996), the medium must be sterile to ensure that rooting is not harmful by the pathogens.

The appropriateness of the medium depends on the species, type of cutting, season, propagation system used as well as cost and availability of the medium ingredients (Macdonald, 1986; Hartmann et al., 2002; Isfendiyaroglu et al., 2009). El- Naggar and 
El-Nasharty (2009) reported that potting media as well as nutritional requirements are the most important factors affecting the rooting and growth of plants. Therefore, to optimize the most successful media for root and shoot development in stem cuttings of 'Phule Arakta' is an early bearing (120-135 days) and high yielding (30-35 kg tree $\left.{ }^{-1}\right)$ variety of pomegranate having desirable fruit quality (glossy, attractive, dark red skin bigger sized fruits, soft sweet seeds and bold red arils) cuttings a study was conducted. Keeping these facts in view, the present study was carried out to identify the most appropriate medium for the better rooting and optimum growth of cuttings of pomegranate cv. Phule Arakta. The study assumes significance as 'Phule Arakta' valued for its high yield, early bearing and fruit quality is becoming a variety of choice among the pomegranate growers.

\section{MATERIALS AND METHODS}

To study the effect of different growing media on the rooting of Punica granatum L. 'Phule Arak$t a$ ' cuttings, an experiment was carried out at ICARCentral Institute for Arid Horticulture at Bikaner during the year 2014-15. The experiment was laid out in randomized complete block design (RCBD) with three replications in four different growing media i.e. sand, perlite, vermiculite and coco peat were used pure or in mixtures i.e. $\mathrm{T}_{1}$ (Sand), $\mathrm{T}_{2}$ (Vermiculite), $\mathrm{T}_{3}$ (Perlite), $\mathrm{T}_{4}$ (Coco peat), $\mathrm{T}_{5}$ (Sand + Coco peat), $\mathrm{T}_{6}$ (Sand + Perlite), $\mathrm{T}_{7}$ (Sand + Vermiculite), $\mathrm{T}_{8}$ (Vermiculite + Coco peat), $\mathrm{T}_{9}$ (Perlite + Vermiculite), $\mathrm{T}_{10}$ (Perlite + Coco peat) and $\mathrm{T}_{11}$ Control (garden soil) at 1:1 (v/v). Twenty centimeter-long hardwood cuttings of five to ten $\mathrm{mm}$ diameter were collected from 'Phule Arakta' trees situated at orchard of ICAR$\mathrm{CIAH}$, Bikaner. Immediately after collection, the base of cuttings was treated for $10 \mathrm{~s}$ with $2500 \mathrm{mg} \mathrm{L}^{-1}$ IBA in a $50 \%$ ethanol solution (96\% purity). Cuttings were inserted in polybags filled with the different medium compositions. The cuttings were planted in mid January, 2015 and irrigated with a sprinkler, there was a mist system to maintain high humidity and to prevent the water loss from the cuttings. Irrigation of the plants was repeated when it was needed. Various observations were recorded after four months of planting i.e. rooting $(\%)$, number of roots, length of roots $(\mathrm{cm})$, fresh weight of roots $(\mathrm{g})$, dry weight of roots $(\mathrm{g})$, number of shoots per cuttings and survival (\%). All the data were subjected to variance of analysis using the SAS (Version 9.3, SAS Institute Inc., Cary, NC, USA). Duncan`s multiple range test was applied at 5 per cent probability level to compare the |differences in the treatment means.

\section{RESULTS AND DISCUSSION}

The cuttings of pomegranate cv 'Phule Arak$t a$ ' showing successful rooting in different media were selected to record the data. Data were analysed as one factor $\mathrm{RCBD}$, and the results are presented under the following heads:

Rooting (\%) : Data recorded for rooting percentage are presented in Table 1. The analysis of variance (ANOVA) showed that planting media had a significant effect on rooting percentage. Mean values of rooting percentage showed that perlite + vermiculite proved to be the best rooting medium with 82.3 percent rooting closely followed by vermiculite + cocopeat giving (81.0 percent) rooting. The minimum rooting (62.0 per cent) was noted in garden soil i.e. control. The main reason behind the efficient performance of perlite + vermiculite may be due to better soil aeration resulting in better rooting percentages. Hartman and Kester (1983) noted that a mixture in equal parts of perlite and vermiculite usually gives better results than either material used alone. Sardoei (2014) also reported that higher rooting percentage $(85 \%)$ was achieved in perlite-silt $(1: 1 \mathrm{v} / \mathrm{v})$ medium in guava which holds high level of water, but non significant differences were observed among other medium used. Although, Swetha (2005) reported improved rooting in Indian lavender in cocopeat substrate over soil. Pieces cuttings are sensitive to oxygen deficiency and go to rotting immediately. If the medium is highly humid, rooting process is delayed as a result of oxygen deficiency (Erstad and Gislerod, 1994). Ansari (2013) reported that vermiculite mixed with sand was the best for higher per cent rooting and root numbers in pomegranate due to more water holding capacity and release of nutrients gradually from vermiculite medium. Isfendiyaroglu et al. (2009) recorded that perlite-vermiculite medium induced very high rooting whereas root production is negatively affected when cuttings of olive grown in sand. Sutter (2005) also found that perlite-vermiculite (2:1 or $3: 1$ ratio) is the most commonly used propagation medium in Californian olive nurseries. Vermiculite has also been found to positively affect the rooting of Iranian cultivars of olive when used as a medium component for cuttings grown under fog conditions (Hosseini et al., 2004). Exadaktylou et al. (2009) found that perlite in combination of peat (total porosity $70 \%$, water holding capacity $30 \%$ ) and perlite (total porosity 75 $\%$, water holding capacity $20 \%$ ) are suitable for rooting in hardwood cuttings of cherry cultivar 'Gisela 5'. Tofanelli et al. (2003) found that the highest rooting percentage was recorded in vermiculite substrate when six rooting substrates i.e. sand, carbonized rice husk, vermiculite, sand + carbonized rice husk, sand + vermiculite, and carbonized rice husk + vermiculite were tested for rooting in peach hardwood cuttings. Denny and Arnold (2001) found the rooting percentage in cuttings of american smoke tree (Cotinus obovatus) was significantly increased with perlite substrate. Similarly, Tsipouridis et al. 
Rajkumar et al. / J. Appl. \& Nat. Sci. 9 (2): 715 - 719 (2017)

Table 1. Effect of different media on the rooting and performance of Pomegranate (Punica granatum L.) cv. 'Phule Arakta' cuttings.

\begin{tabular}{lcccc}
\hline Media & Rooting (\%) & No. of roots/ cutting & Length of root (cm) & Survival (\%) \\
\hline Sand & $69.33^{\mathrm{D}}$ & $26.33^{\mathrm{CD}}$ & $19.00^{\mathrm{DE}}$ & $67.33^{\mathrm{E}}$ \\
Vermiculite & $79.33^{\mathrm{AB}}$ & $28.67^{\mathrm{BC}}$ & $20.00^{\mathrm{CD}}$ & $77.33^{\mathrm{ABC}}$ \\
Perlite & $78.33^{\mathrm{AB}}$ & $28.00^{\mathrm{BC}}$ & $18.00^{\mathrm{EF}}$ & $71.67^{\mathrm{CDE}}$ \\
Coco peat & $72.00^{\mathrm{CD}}$ & $29.00^{\mathrm{B}}$ & $21.00^{\mathrm{BC}}$ & $67.00^{\mathrm{E}}$ \\
Sand + Coco peat & $72.00^{\mathrm{CD}}$ & $28.00^{\mathrm{BC}}$ & $21.00^{\mathrm{BC}}$ & $70.00^{\mathrm{DE}}$ \\
Sand + Perlite & $75.33^{\mathrm{BC}}$ & $29.67^{\mathrm{B}}$ & $22.33^{\mathrm{AB}}$ & $73.33^{\mathrm{BCD}}$ \\
Sand + Vermiculite & $79.00^{\mathrm{AB}}$ & $33.00^{\mathrm{A}}$ & $23.67^{\mathrm{A}}$ & $77.00^{\mathrm{ABC}}$ \\
Vermiculite + Coco peat & $81.00^{\mathrm{A}}$ & $30.00^{\mathrm{B}}$ & $22.00^{\mathrm{AB}}$ & $79.00^{\mathrm{AB}}$ \\
Perlite +Vermiculite & $82.33^{\mathrm{A}}$ & $32.67^{\mathrm{A}}$ & $23.00^{\mathrm{A}}$ & $80.33^{\mathrm{A}}$ \\
Perlite+ Coco peat & $78.00^{\mathrm{AB}}$ & $32.67^{\mathrm{A}}$ & $23.67^{\mathrm{A}}$ & $76.00^{\mathrm{ABC}}$ \\
Control (Garden soil) & $62.00^{\mathrm{E}}$ & $24.67^{\mathrm{D}}$ & $17.00^{\mathrm{F}}$ & $60.00^{\mathrm{F}}$ \\
General Mean & 75.33 & 29.33 & 20.97 & 72.64 \\
CV(\%) & 4.37 & 5.12 & 4.80 & 4.59 \\
SE(d) & 2.688 & 1.225 & 0.823 & 2.725 \\
LSD at 5\% & 5.6066 & 2.5556 & 1.716 & 5.6845 \\
\hline
\end{tabular}

Means with at least one letter common are not statistically significant $(\mathrm{p}<0.05)$ using LSD Test

(2004) found that perlite was the most suitable rooting media for peach hardwood cuttings, whereas Ercisli et al. (2002) recorded the maximum rooting percentage in peat + perlite and peat + sawdust substrates for kiwifruit (Actinidia chinensis) hardwood cuttings.

Number of roots per cutting: Data noted for number of roots per cutting are given in Table 1 . The analysis of variance showed that the number of roots per cutting was significantly affected by treatments. The means in Table-1 indicate that maximum number of roots per cutting (32.67) was obtained in perlite + vermiculite and perlite + cocopeat media each while minimum number of roots per cutting (24.67) was noted in control. Swetha (2005) recorded that highest number of roots were obtained in cocopeat substrate as compared to soil in Indian lavender. Mamba and Wahome (2010) found more number of roots per cutting in geraniums by using a mixture of garden soil, compost and sand as compared to garden soil alone. Khayyat et al. (2007) observed that leaf mould and sand substrates induced better root formation and growth in Epipremnum aureum due to better drainage and water holding capacity. The basis for the best performance of perlite + vermiculite may be proper aeration and optimum moisture retention for better rooting in cuttings. The cuttings raised in perlite + vermiculite substrate showed more number of roots because this medium remains loose enough to allow air to reach the newly forming roots and also holds enough water to prevent the lower end of the cuttings from drying.

Root length: The data related to root length is presented in Table 1. The analysis showed that media had significant effect on the length of root per plant. The means of roots length show that the maximum root length $(23.67 \mathrm{~cm})$ was measured in perlite + cocopeat followed by $23.0 \mathrm{~cm}$ in perlite + vermiculite while the minimum root length $(17.0 \mathrm{~cm})$ was recorded in control. These results are in accordance with the findings of Swetha (2005) who found that longer roots were obtained in cocopeat substrate as compared to soil in Indian lavender. However, Lal and Dana (1985) found that root length was more in sand for carnation. Mamba and Wahome (2010) found that highest root length in geranium cuttings rooted in compost could probably be attributed to higher water holding capacity of the medium. The main reason for the better root length is the downward moment of water and nutrients because the roots had to absorb the water and nutrients there for they increased their length thus, aeration also plays a very significant role in root elongation in cuttings.

Fresh and dry root weight: The data related to fresh and dry root weight of 'Phule Arakta' cuttings are given in Fig. 1 which showed that different soil media had significant effect on the root fresh weight per cutting. The means of root fresh weight per plant shows that maximum fresh root weight $(2.08 \mathrm{~g})$ was obtained in perlite + vermiculite followed by $2.03 \mathrm{~g}$ in vermiculite + cocopeat, while the minimum fresh root weight $(1.57 \mathrm{~g})$ was observed in control. Similarly, different soil media showed significant effect on the root dry weight per plant. The means of root dry weight per plant showed that maximum dry root weight $(0.61 \mathrm{~g})$ was obtained in perlite + vermiculite followed by $0.60 \mathrm{~g}$ in vermiculite + cocopeat while the minimum dry root weight $(0.47 \mathrm{~g})$ was observed in control. These results are in accordance with the findings of Isfendiyaroglu et al. (2009) who recorded that sand-perlite $(1: 2)$ gave the highest fresh weights and dry root weights in olive cuttings which probably due to good water holding capacity and porosity of 


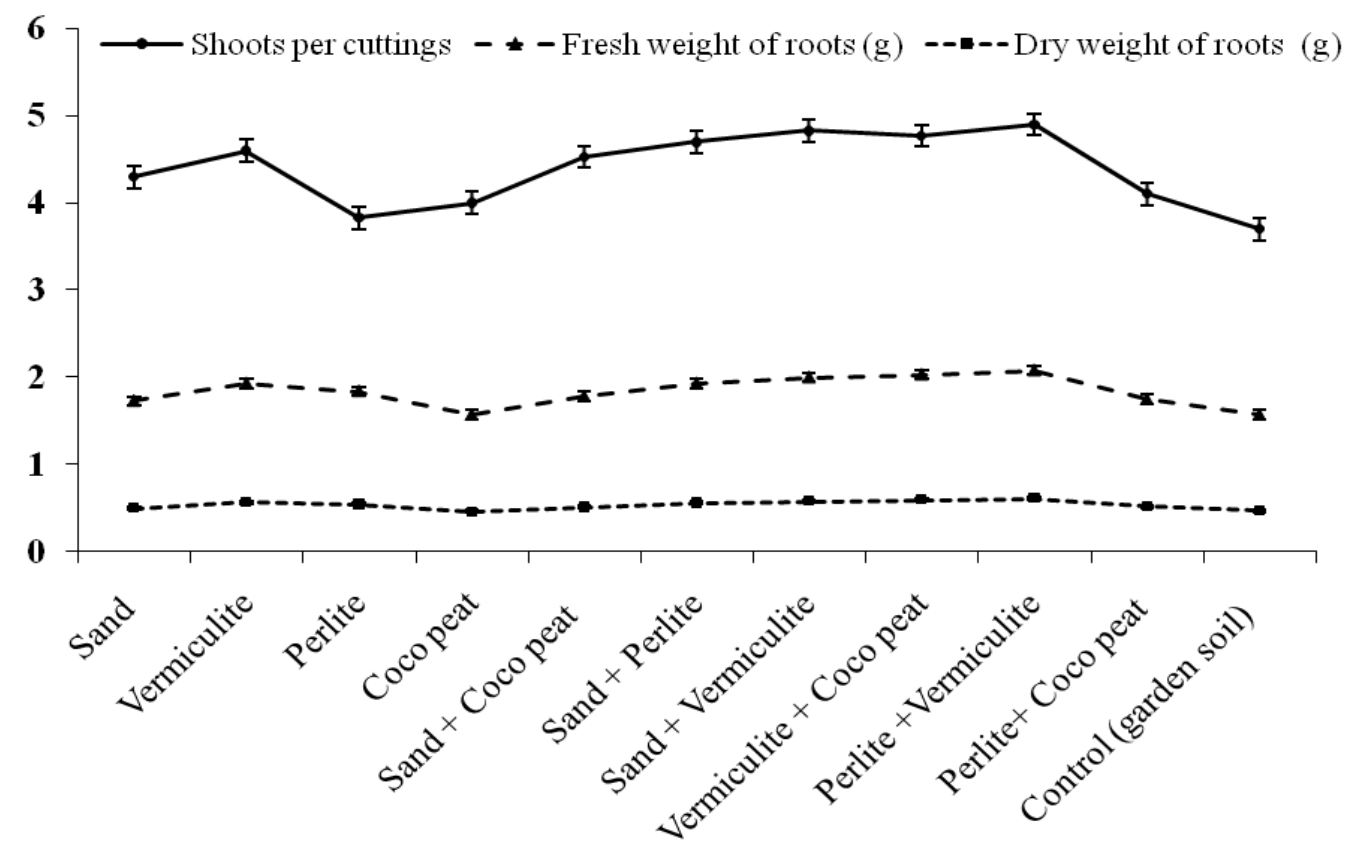

Fig. 1. Effect of different media on fresh, dry weight of roots and number of shoots per cutting in Pomegranate (Punica granatum L.) cv. 'Phule Arakta' cuttings.

perlite. Khayyat et al. (2007) recorded that improved fresh and dry root weights were in pothos by using cocopeat substrate. Kakoei and Salehi (2013) found that fresh and dry root weight and root length were higher in the media containing only perlite in spathiphyllum. However, Badrzad et al. (2012) did not find significant difference between sand and sand-perlite $(1: 1 \mathrm{v} / \mathrm{v})$ regarding rooting traits in cuttings of apple MM106. Interestingly, sand was more efficient than sand-perlite $(1: 1 \mathrm{v} / \mathrm{v})$ with respect to root dry weight.

Shoots per cutting: Data pertaining to shoots per cutting are displayed in Fig. 1. The analyses of variance indicated that different planting media had significant effect on shoots per cutting. Means of shoots per cutting indicated that the maximum (4.9) shoots per cutting was obtained in perlite + vermiculite followed by 4.83 in sand + vermiculite while the minimum shoots per cutting (3.7) were obtained under control. However, Mamba and Wahome (2010) found that more number of shoots, shoot length and number of leaves per cuttings were obtained in garden soil in geranium. Similarly, Sardoei (2014) reported significant difference in number of shoots by using soil loam, perlite and sand-perlite $(1: 1 \mathrm{v} / \mathrm{v})$ substrates in guava cuttings.

Survival (\%): Data pertaining to rooting percentage are displayed in Table 1. Means of survival percentage indicated that the maximum $(80.3 \%)$ survival percentage was obtained in perlite + vermiculite followed by 79 per cent in vermiculite + cocopeat while the minimum survival percentage ( 60 per cent) was obtained under control. Altman and Freudenberg (1983) found that rooting substrates are important for the quality of rooted cuttings in geranium and perlite was found superior over others substrates and resulted in better quality and survivability of the rooted cuttings. Gerrakakis and Ozkaya (2005) reported that rooting and survival rates of 'Ayvalik' olive cuttings significantly reduced in sand, but sand-perlite mixtures significantly improved rooting and survival of rooted cuttings compared to sand alone. However, Macdonald (1986) found that some species of Prunus, Hydrangea and Ilex showed good rooting in sand.

\section{Conclusion}

It is established that rooting substrates have their own effectiveness. In this work, the percentage of rooted cuttings ranged from $62.0 \%-82.33 \%$ depending on the substrate used. The present results showed that perlite + vermiculite $1: 1(\mathrm{v} / \mathrm{v})$ medium, however, showed good response in rooting, number of roots, fresh weight of roots, dry weight of root, shoots per cutting and survival, while vermiculite + cocopeat $1: 1$ (v/v) also led to more than eighty percent of cuttings taking root, while garden soil i.e. control and sand gave very low rooting percentages. On the basis of results obtained from this study, it is concluded that propagation of pomegranate (Punica granatum L.) $\mathrm{cv}$. 'Phule Arakta' through cuttings is not a simple task without the use of rooting substrate under arid conditions. A $1: 1(\mathrm{v} / \mathrm{v})$ ratio of perlite and vermiculite provided a clean, well-drained media which was favorable to high rates of rooting and better root and shoot development. Thus, it is recommended that pomegranate cultivar 'Phule Arakta' cuttings should be 
propagated by using perlite + vermiculite $1: 1(\mathrm{v} / \mathrm{v})$ followed by vermiculite + cocopeat $1: 1(\mathrm{v} / \mathrm{v})$ may be appropriate alternatives to conventional garden soil for better root formation and growth. Further effort is required to decide the best perlite + vermiculite proportions. This work also records the affirmative effects of vermiculite + coco peat in 1:1 (v/v) ratio. The variation in the quality of the root and shoot characteristics by using various rooting substrates can be accredited to the direct consequence of the medium on the basal portion of the cutting.

\section{ACKNOWLEDGEMENTS}

Authors thankfully acknowledge the Director, ICARCIAH,Bikaner for providing necessary facilities and financial help.

\section{REFERENCES}

Altman, A., Freudenberg, D. (1983). Quality of Pelargonium graveolens cuttings as affected by the rooting medium. Sci Hortic., 19: 379-385

Ansari, K. (2013). Effects of different collecting time and different medium on rooting of pomegranate "Malas torsh cv." cuttings. Bull. Env. Pharmacol. Life Sci., 2 (12): 164-168

Badrzad. D., Imani, A., Piri, S. and Massomi, S.H. (2012). 7th Iranian congress of horticulture, 14-17 September, University of Isfahan Pp. 509-511

Denny, C. and Arnold, A. (2001). Interactions among rooting substrate, phenological stage of cuttings and auxin concentration on the rooting of Cotinus obovatus. $J$. Appl. Hort., 1: 13-16

El-Naggar, A. H. and El-Nasharty, A. B. (2009). Effects of growing media and mineral fertilisation on growth, flowering, bulb productivity and chemical constituents of Hippeastrum vittatum, Herb. Am-Euras J Agric Environ Sci., 6(3): 360-371

Ercisli, S., Anapali, O., Esitken, A., Sahin, U. (2002). The effects of IBA, rooting media and cutting collection time on rooting of kiwifruit.Gartenbauwissenschaft, 67:34-38

Erstad, J. L. F. and Gislerod, H. R. (1994). Water uptake of cuttings and stem pieces as affected by different anaerobic conditions in the rooting medium. Scientia Hort., 58(1-2): 151-160

Exadaktylou, E., Thomidis, T., Grout, B., Zakynthinos, G. and Tsipouridis, C. (2009). Methods to improve the rooting of hardwood cuttings of the 'Gisela 5' cherry rootstock. Hort Technology, 19(2): 254-259

Gerrakakis, A. C. and Ozkaya, M. T. (2005). Effects of cutting size, rooting media and planting time on rooting of Domat and Ayvalik olive (Olea europaea L.) cultivars in shaded polyethylene tunnel (spt.). Tarim Bilimleri Dergisi, 11(3): 334-338

Hartman, H. T. and Kester, D. E. (1983). Plant propagation, principles and practices. Prentice-Hall, Inc., Englewood Cliffs, New Jersey.

Hartmann, H. T., Kester, D. E., Davies, Jr., F. T., and Geneve, R. L. (2002). Seventh ed. Hartmann and Kester's Plant Propagation: Principles and Practices Prentice-Hall, Inc., Englewood Cliffs, New Jersey Pp. 880

Hosseini, S. M., Sadeghi, H., Esmati, A., Nourmohammadi,
Z., Keshavarz, M. A., Hosseinimaziani, M. (2004). Effect of media on rooting cuttings of four olive cultivars. $5^{\text {th }}$ International Symposium on Olive Growing, 27/9-2/102004, İzmir, Turkey. Abst. 234

Isfendiyaroglu, M., Ozeker, E. and Baser, S. (2009). Rooting of 'Ayvalik' olive cuttings in different media. Span. J. Agri. Res., 7(1): 165-172

Kakoei, F. and Salehi, H (2013). Effects of different pot mixtures on spathiphyllum (Spathiphyllum wallisii Regel) growth and development. J. Cent. Euro. Agri., 14(2): $140-148$

Khayyat, M., Nazari, F. and Salehi, H. (2007). Effect of different pot mixture on pothos (Epipremnum aureum Lindl and Andre 'Golden Pothos') growth and development. Am. J. Agri. Environ. Sci., 2 (4): 341-348

Lal, S. D. and Dana, N. S. (1985). Rooting of carnation cuttings as influenced by different rooting media. Progressive Hort., 17(2): 145-147

Landis, T.D. (1995). Improving polybag culture for sustainable nurseries. Forest Nursery Notes, Pp. 6-7

Larson, E. L. (1980). Introduction to floriculture. Academic Press London. P. 607

Macdonald, B. (1986). Fourth printing, Timber Press, Portland, Oregon, Pp: 669

Mamba, B. and Wahome, P. K. (2010). Propagation of geranium (Pelargonium hortorum) using different rooting medium components. Am-Euras. J. Agri. Environ. Sci., 7: 497-500

Miller, J. H. and Jones, N. (1995). Organic and compost-based growing media for tree seedling nurseries. World Bank Tech. Pap. No. 264, Forestry Series. Washington, DC: The World Bank. P. 75

Paradiso, R., and de Pascale, S. (2008). Effects of coco fiber addition to perlite on growth and yield of cut gerbera. Acta Hortic., 779: 529-534

Rajkumar, Gora, Kumar, J. S., Singh, R., Kumar, A.,Gajender. A. (2016). Establishment, survival and growth of pomegranate cuttings with different concentrations of indole butyric acid and rooting substrates. Ecol. Environ. Cons., 22: 321-327

Sardoei, A. S. (2014). Effect of different media of cuttings on rooting of guava (Psidium guajava L.). Euro. $J$. Expt. Biol., 4(2):88-92

Sutter, E. G. (2005). Olive cultivars and propagation. In: Olive production manual (Sibbett G.T. and Ferguson L., eds.), 2nd ed., Univ California, Agriculture and Natural Resources, Publ. 3353, Pp. 19-25

Swetha, H. (2005). Propagation of Indian lavender (Bursera delpechiana Poiss. ex Engl.) through cuttings under mist. M.Sc. (Ag.) Thesis. University of Agricultural Sciences, Dharwad, India.

Tofanelli, M., Rodrigues, J., Ono, E. (2003). Rooting of peach cv. 'Okinawa' hardwood cuttings at different stem diameters, substrates, and pots. Ciencia Rural, 33:437-442

Tsipouridis, C. G., Isaakidis, A., Manganaris, A., Therios, I. and Michailidis, Z. (2004). Propagation and field performance of own-rooted peach trees. Aust. J. Exp. Agr., 44: 1225-1229

Vision NRCP (2015). Vision 2050, National Research Centre on Pomegranate, Sholapur, Maharashtra.

Walston, B. (1996). Propagation of woody $\mathrm{P}=$ plants by cuttings. Retrieved from www.evergreengardenworks.com/ cuttings.htm 